\title{
i saw a tall black poodle today
}

\author{
kim dawn
}

\begin{abstract}
j'ai vu un grand caniche noir aujourd'hui
Un jour en marchant au soleil, kim dawn voit un caniche noir qui déclenche ses souvenirs d'enfance avec toutes les retombées émotionnelles qui les accompagnent. Elle se souvient avec détail des framboises le long de sa route, de la grange décrépite où elle devait chier et uriner dans un trou creux et effrayant qui avalait tout, des oiseaux et des chauve-souris qui vivaient dans la grange, et de l'eau, toujours de l'eau, des rivières, des lacs et des jets d'eau. Elle se souvient de la période la plus heureuse de sa vie, des géraniums roses, d'un petit chien, et du pain blanc maison avec de la mélasse. Elle se souvient de sa mère qui lui disait qu'elle n'était que peau et os, mais elle était beaucoup plus, un composé de son bonheur et de son expérience, incapable d'exprimer l'intensité de ses impressions sensuelles.
\end{abstract}

analysand 14th, 1997). i saw a tall black poodle today (saturday, june it drove me back, way back

cousins . remembered the blind black poodle from my

his eyes were like glass. a

blue white water/glass. there was a field. it was pouring

back too

fast. i tried to tell him about it. i was there momentarily. (stillness trembles always.)

absent in my presence, disembodied. embodied in the past. icouldn't utter it all fast enough. i could smell the place. $i$ could smell the time. my amnesiac body was loosing its slippery little girl fingers on these moments. they were fleeting. and i was scared. 
i was scared.

i conjured up ;

bridge

(a.) raspberries along the way. (b.) the walk to the beneath. (d.) there where (c.)the eels swam low and large which were poisonous. (e.) there were black berries too, decrepit barn (f.) where we had to shit and pee in a hole too deep you never heard it land. it swallowed everything up. (g.) there were families of swallows who swooped by the field near the barn. they would hurt you to save their baby s / wallows. they would eat their babies if they were starving. (h.) there were small bats inside hanging inside. still. waiting. (i.) there was a small lake out back with tall grass and lots of large friendly flies as large as my small fists. (j.) there was also a river, palette river which we had to drive to. we drove in the back of the truck. we jumped off big rocks and plummeted in the holes of our hot black tire tubes. (k.) there was a tap of huge gushing natural spring water along the way to the bridge. our mouths. underneath. so cold. so cold. the taste of metal resting upon our small pink lips.

analyst where were you when this onslaught of fragmentation occurred

analysand i was walking in the hot sun.

analyst how did you feel

analysand i felt like i was under under under. flailing falling. i wanted to cry. i wanted to go back there. but be happy. this my childhood. this and my was the happiest place of house. she had things like: grandmother's

1. thin (seethrough) orange curtains. 2. pink geraniums that smelt like dying breath. 3. a dog, captain, 
on a short leash. 4. a barn, which was falling in on itself gradually and did so the moment she died. 5. a long table. 6. homemade white bread. molasses. thick hard chunks of yellow butter. cold meats. refried potatoes. iced water in a yellow plastic pitcher that tasted like the fridge. 7. my grandfathers war medals. 8. framed photos. fading. 9. a tv with a full ashtray beside it, this is the room that christmas tree went in. this is the only time $i$ went into that room. i only ever saw my grandfather at mealtime. 10. large, tall grass field that went on and on. my cousins and i would make impressions and rooms with our bodies in that grass.

analyst can you picture you then

analysand i was scrawny. with bony legs. my mom said i was going to fade away. (i believed her) she said i was nothing but skin and bones. i had short red hair. fair skin. a few freckles. blue eyes. $i$ had no mouth. 